\title{
Cloning and Expression of Cyclodextrin Glycosyltransferase Gene from Paenibacillus sp. T16 Isolated from Hot Spring Soil in Northern Thailand
}

\author{
Ratiya Charoensakdi', Shuichiro Murakami ${ }^{2}$, Kenji Aoki ${ }^{2}$, \\ Vichien Rimphanitchayakit ${ }^{1}$ and Tipaporn Limpaseni ${ }^{1, *}$ \\ ${ }^{1}$ Department of Biochemistry, Faculty of Science, Chulalongkorn University,Bangkok 10330, Thailand \\ ${ }^{2}$ Department of Biofunctional Chemistry, Faculty of Agriculture, University of Kobe, Japan
}

Received 13 June 2006, Accepted 13 December 2006

\begin{abstract}
Gene encoding cyclodextrin glycosyltransferase (CGTase), from thermotolerant Paenibacillus sp. T16 isolated from hot spring area in northern Thailand, was cloned and expressed in E. coli (JM109). The nucleotide sequences of both wild type and transformed CGTases consisted of 2139 bp open reading frame, 713 deduced amino acids residues with difference of 4 amino acid residues. The recombinant cells required $24 \mathrm{~h}$ culture time and a neutral $\mathrm{pH}$ for culture medium to produce compatible amount of CGTase compared to $72 \mathrm{~h}$ culture time and $\mathrm{pH} \mathbf{1 0}$ for wild type. The recombinant and wild-type CGTases were purified by starch adsorption and phenyl sepharose column chromatography and characterized in parallel. Both enzymes showed molecular weight of $77 \mathrm{kDa}$ and similar optimum pHs and temperatures with recombinant enzyme showing broader range. There were some significant difference in pH, temperature stability and kinetic parameters. The presence of high starch concentration resulted in higher thermostability in recombinant enzyme than the wild type. The recombinant enzyme was more stable at higher temperature and lower $\mathrm{pH}$, with lower $K_{m}$ for coupling reaction using cellobiose and cyclodextrins as substrates.
\end{abstract}

Keywords: Coupling activity, Recombinant cyclodextrin glycosyltransferase

\section{Introduction}

Cyclodextrins (CDs) are a family of cyclic oligosaccharides composed of $\alpha-(1,4)$ linked glucopyranose units. Cyclodextrins mainly consist of 6,7 or 8 glucose residues, designated as $\alpha$-,

*To whom correspondence should be addressed.

Tel: 66-2218-5423; Fax: 66-2218-5418

E-mail: tipaporn.1@chula.ac.th $\beta$ - and $\gamma$-cyclodextrins ( $\alpha$-, $\beta$ - and $\gamma$-CDs) respectively. Each cyclodextrin is a torus (doughnut-shaped) molecule. The cyclodextrin cavity thus forms a hydrophobic microenvironment in aqueous solutions, making cyclodextrin an ideal host for an unusually wide variety of guest molecules of the appropriate size and polarity (Szejtli, 1998). Incorporation of guest compounds into the $\mathrm{CD}$ cavity lead to many favorable changes in the physical and chemical properties of the molecules (Schmid, 1989). CDs were applied for improvement of products in various industries such as cosmetics, pharmaceuticals, food and others (Stella and Rajewski, 1997; Baudin et al., 2000; Hirose and Yamamoto, 2001; Mabuchi and Ngoa, 2001; Buschmann and Schollmeyer, 2002). CDs are products of the reaction catalyzed by cyclodextrin glycosyltransferase (CGTase) with polysaccharides or starch or some other carbohydrates as substrates (Kobayashi, 1996). CGTases were reported to be produced by many bacterial strains, mainly Bacilli. Industrial production of CDs was usually carried out at high temperature; therefore, bacteria which can grow and produce CGTase at high temperature are desirable. Recently, there were attempts to isolate thermotolerant CGTase-producing bacteria. This work reported on the finding of a Paenibacillus sp. isolated from hot spring area in northern Thailand which grew and produced CGTase at high temperature. Its CGTase gene was successfully cloned into E. coli. The transformant produced some improved properties of the enzyme.

\section{Materials and Methods}

Chemicals. Corn starch was obtained from Sigma Chemical Co. (Saint Louis). Luria-Bertani (LB) media and Bacto agar for bacterial culture were acquired from Difco Laboratories (Detroit). Restriction enzymes were the products of (Amercham bioscience Co. and NEB Co.) and were used under the supplier's instructions. All other chemicals were commercial products of analytical grade or molecular biological grade. 
Bacterial strains and plasmid. Paenibacillus sp. T16, isolated from Tak province in northern Thailand by our research group, was used as source of CGTase gene and enzyme. E. coli JM109 was employed as host cells with GGEM $^{\circledR}-\mathrm{T}$ Easy (Qiagen) as the plasmids.

Culture media. Modified Horikoshi medium containing 1.0\% soluble starch, $0.5 \%$ peptone, $0.5 \%$ yeast extract, $0.1 \% \mathrm{~K}_{2} \mathrm{HPO}_{4}$, $0.02 \% \mathrm{MgSO}_{4} \cdot 7 \mathrm{H}_{2} \mathrm{O}$ and $0.75 \% \mathrm{Na}_{2} \mathrm{CO}_{3}$, was used as culture medium for wild-type T16 (Horikoshi, 1987). LB broth containing $1.0 \%$ soluble starch was employed for culturing the transformant.

Measurement of CGTase activity and protein concentration. For primary screening, CGTase was identified by measuring its dextrinizing activity by monitoring the absorbance of starch-iodine complex at $600 \mathrm{~nm}$ (Fuwa. 1954) with slight modification. Enzyme sample (10-1000 $\mu \mathrm{l})$ was incubated with $0.3 \mathrm{ml}$ starch substrate $(0.2$ $\mathrm{g} \%$ soluble potato starch in $0.2 \mathrm{M}$ phosphate buffer, $\mathrm{pH} 6.0$ ) at $40^{\circ} \mathrm{C}$ for $10 \mathrm{~min}$. The reaction was stopped with $4 \mathrm{ml}$ of $0.2 \mathrm{~N} \mathrm{HCl}$ and $0.5 \mathrm{ml}$ of iodine reagent $\left(0.02 \% \mathrm{I}_{2}\right.$ in $\left.0.2 \% \mathrm{KI}\right)$ was added. The mixture was adjusted to a final volume of $10 \mathrm{ml}$ with distilled water and the absorbance at $600 \mathrm{~nm}$ was measured. For control tube, $\mathrm{HCl}$ was added before the enzyme sample. One unit of enzyme was defined as the amount of enzyme which produced $10 \%$ reduction in the intensity of the blue color of the starch-iodine complex per minute under the described condition. Cyclization activity was determined by the phenolphthalein method (Goel and Nene, 1995). To $1.25 \mathrm{ml}$ of $4.0 \%$ soluble starch, $0.25 \mathrm{ml}$ purified CGTase was added. The reaction mixture was incubated for $30 \mathrm{~min}$ at $60^{\circ} \mathrm{C}$. The reaction was stopped by boiling for $5 \mathrm{~min}$ and $1.0 \mathrm{ml}$ of the reaction mixture was incubated with $4.0 \mathrm{ml}$ of phenolphthalein solution. The decrease in phenolphthalein absorption at $550 \mathrm{~nm}$ reflected the amount of CD in the reaction which was quantitated from calibration curve. One unit of activity was defined as the amount of enzyme able to produce 1 mole of $\beta$-CD per minute under the appropriate condition. Monitoring CGTase activity on agar plate was performed by pouring mixture of methyl orange and phenolphthalein on Horikoshi medium (Park et al., 1989) or LB plate in the presence of $1 \%$ soluble starch. Protein concentration was monitored by absorbance at $280 \mathrm{~nm}$ or using reaction with Coomassie blue-G according to Bradford (Bradford, 1976).

Cloning of CGTase gene. Cloning of CGTase gene was performed according to Sambrook (Sambrook et al., 1989). CGTase gene was prepared from genomic DNA of Paenibacillus sp. T16 by PCR reaction. Forward and reverse primers, containing 24 nucleotides were designed from N- and C- terminal sequence of Paenibacillus sp. A11 (Rimphanitchayakit et al., 2005). The PCR product was purified by Geneclean III kit and ligated into PGEM $^{\mathbb{Q}}-\mathrm{T}$ easy vector and transformed by electroporation into E. coli JM109. Positive colonies were identified by culturing on LB agar plates containing $1 \%$ soluble potato starch, $50 \mu \mathrm{g} / \mu \mathrm{l}$ of ampicillin, $0.002 \% \mathrm{X}$-gal and $0.0025 \%$ IPTG.

DNA sequencing. The plasmid DNA was isolated and purified using a Qiaprep Spin Miniprep Kit from Qiagen (Valencia). PCR was performed with purified plasmid DNA as a template, M13 reverse and M13 forward (-20) primers, and Dye Terminator Cycle Sequencing Ready mixture (Perkin Elmer) according to the manufacturer's instructions. DNA sequences were determined by dye-terminator cycle sequencing with an automated DNA sequencer (Beckman Coulter, CEQ8000) and the results were analyzed using GENETYX-WIN software. Nucleotide and amino acid sequence comparisons were performed using BLAST and Clustal W, respectively.

Expression and purification of CGTases from recombinant and wild type T16. T16 and its transformant (pT16) were cultured in the appropriate liquid culture media in which CGTase were found to be optimally produced. T16 was grown in $1200 \mathrm{ml}$ of Horikoshi medium pH 10.0 containing $1 \%$ soluble corn starch for $72 \mathrm{~h}$ at $40^{\circ} \mathrm{C}$ while the recombinant $E$. coli was grown in $1,200 \mathrm{ml}$ of $\mathrm{LB}$ containing $1 \%$ soluble corn starch in the presence of $100 \mathrm{mg} / \mathrm{ml}$ ampicillin for $24 \mathrm{~h}$ at $37^{\circ} \mathrm{C}$. The crude enzymes were collected from the supernatant after centrifugation at $6,500 \mathrm{~g}$ for $15 \mathrm{~min}$ at $4^{\circ} \mathrm{C}$ and subjected to purification by starch adsorption (Kato and Horikoshi, 1984). Corn starch was oven dried at $120^{\circ} \mathrm{C}$ for $30 \mathrm{~min}$ and cooled down to room temperature. It was then gradually sprinkled into stirring crude CGTase broth to make 5\% concentration. After $3 \mathrm{~h}$ of continuous stirring, the starch cake was collected by centrifucation at $8,000 \mathrm{~g}$ for $30 \mathrm{~min}$ and washed twice with $10 \mathrm{mM}$ Tris- $\mathrm{HCl} \mathrm{pH} 8.5$ containing $10 \mathrm{mM} \mathrm{CaCl}_{2}$ (TB1). CGTase was eluted from the starch cake with $0.2 \mathrm{M}$ maltose in TB1 (2X $125 \mathrm{ml}$ for starting broth of 1 liter) with stirring for $30 \mathrm{~min}$. The eluate was collected by centrifugation at $10,000 \mathrm{~g}$ for $30 \mathrm{~min}$. The solution was dialyzed against three changes of distilled water at $4^{\circ} \mathrm{C}$. and subjected to phenyl-sepharose column. The purified enzymes were subjected to 7.5\% Sodium dodecylsulfate polyacrylamide gel electrophoresis (SDS-PAGE) (Bollag and Edelstein, 1991), using the Laemmli buffer system (0.25 M Tris, $1.92 \mathrm{M}$ Glycine, 1\% SDS, pH 8.3).

Determination of kinetic parameters. The sugar most active towards $\beta-\mathrm{CD}$ in coupling reaction was determined by incubation of $17 \mathrm{mM} \beta-\mathrm{CD}$ with $20 \mathrm{mM}$ of different sugars at $55^{\circ} \mathrm{C}$ in the presence of CGTase for $10 \mathrm{~min}$ and reaction stopped by boiling for $5 \mathrm{~min}$. The most active sugar was used as sugar acceptor in subsequent study of kinetic parameters with several CDs and their derivatives as oligosaccharide donors. Kinetic parameters of the coupling reaction were determined by incubating various concentrations of $\alpha-\beta$ - or $\gamma$-cyclodextrins and their derivatives (0.5-15 mM) with $10 \mathrm{mM}$ cellobiose as glucosyl acceptor at $55^{\circ} \mathrm{C}$. $50 \mathrm{mM}$ acetate buffer, $\mathrm{pH} 6.0$ was added to make the total volume of reaction mixture $0.25 \mathrm{ml}$. Cyclodextrin and cellobiose were preincubated for $5 \mathrm{~min}$ at $55^{\circ} \mathrm{C}$. The reaction was started with $10 \mathrm{ml}$ of $0.88 \mathrm{mg} / \mathrm{ml}$ of purified CGTase. Boiling for $5 \mathrm{~min}$ stopped the reaction. Subsequently, 0.2 units of Aspergillus niger glucoamylase $(10 \mathrm{ml})$ was then added to convert linearized oligosaccharides to glucose. The released reducing sugars was measured by the dinitrosalicylic acid method as described in section 2.9.3. $K_{m}$ and $V_{\text {max }}$, were determined from the Michealis-Menten equation using nonlinear least square regression analysis of the EZ-FIT V1.1 Computer program. 


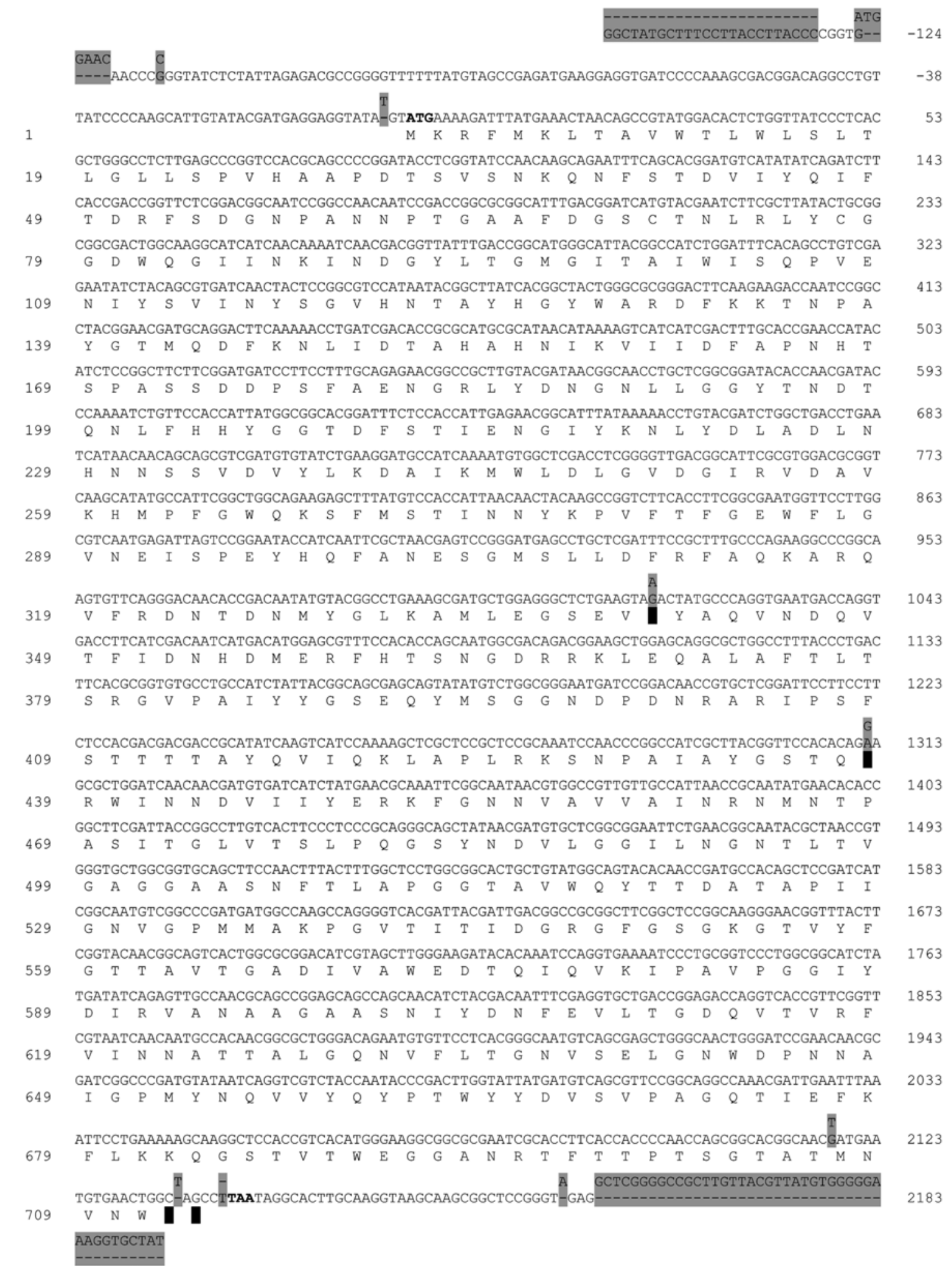

Fig. 1. Nucleotide and deduced amino acid sequences of CGTases of T16 and pT16. The nucleotide sequence of T16 was numbered and shown at the right end, beginning with the first base of the ATG initiator codon and ending with TAA codon. The nucleotide sequence of pT16 were shown only at the positions different from T16 and appeared as grey shaded bases directly above the corresponding bases of T16. The deduced amino acid residues of T16 were shown as single letter below its nucleotide sequence, numbered at left end. Amino acid sequence of pT16 were shown only at the residues different from T16 and appeared as black shaded directly below the corresponding amino acids in T16. Gaps were indicated by dashes. 


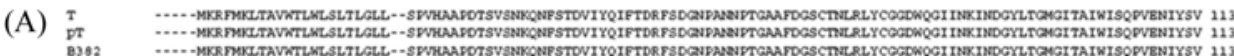

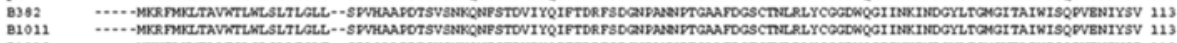

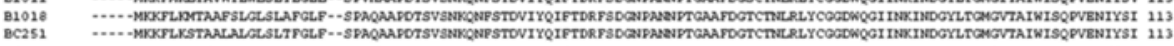

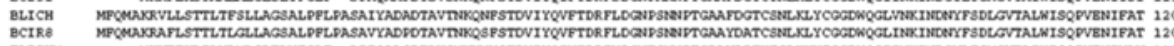

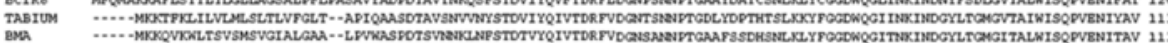

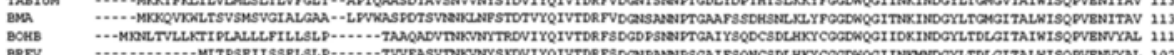

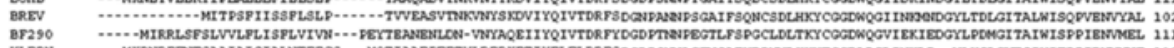

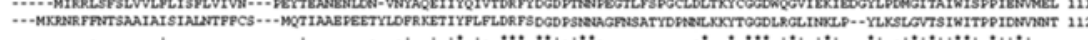

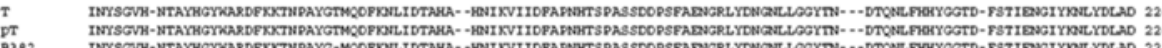

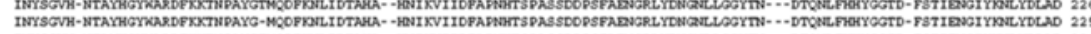

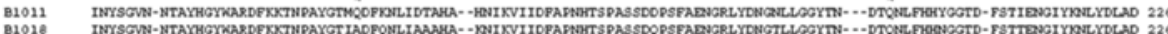

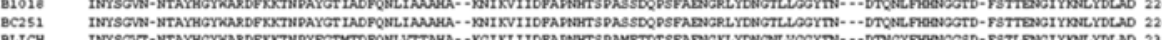

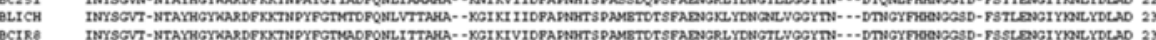

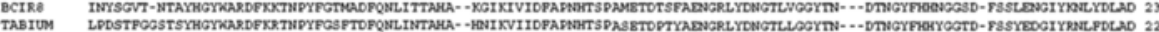

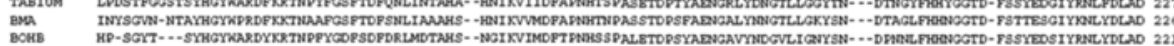

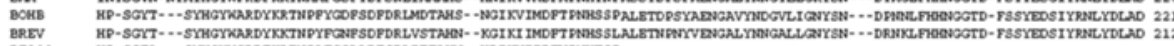

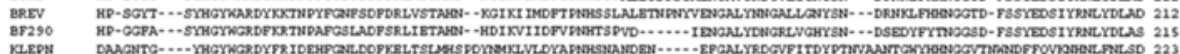

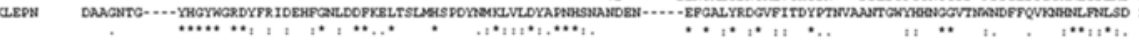

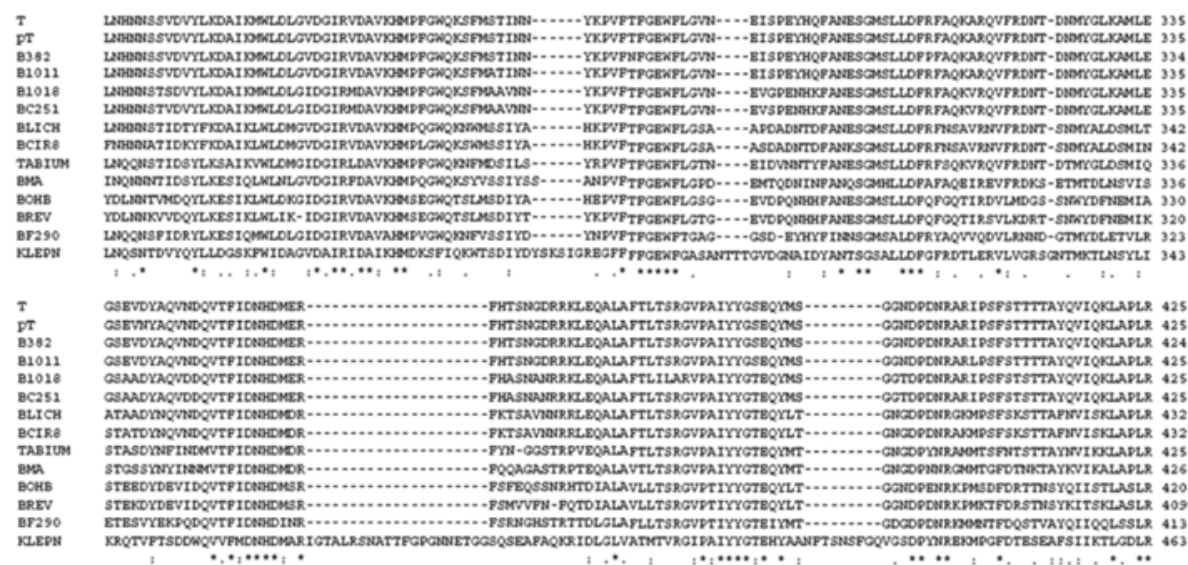

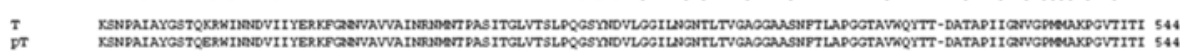

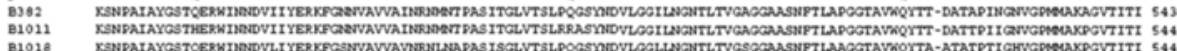

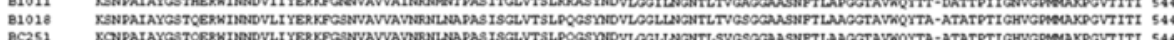

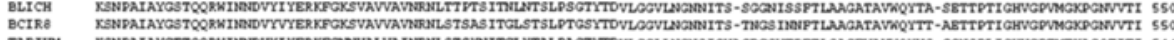

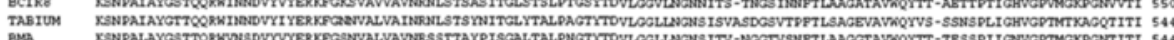
BОК

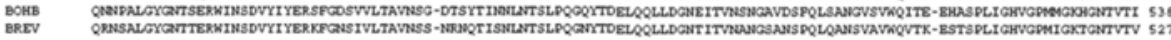

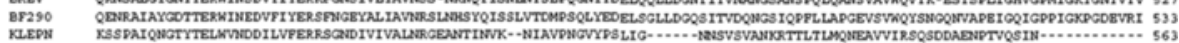
. . .

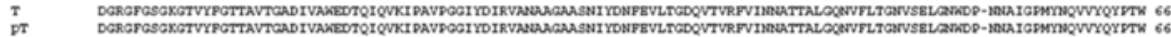

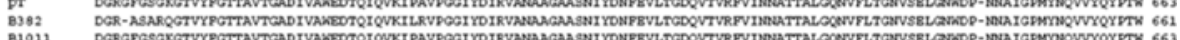

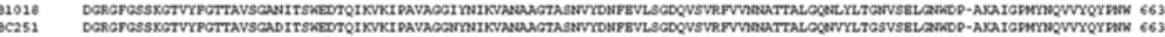

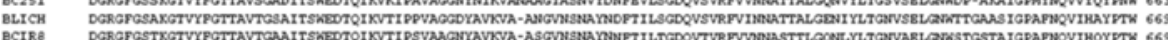

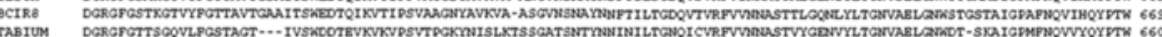

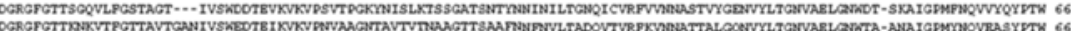

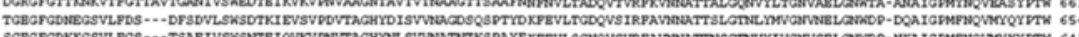

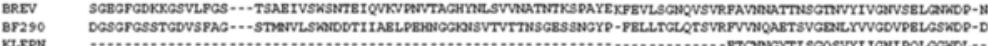

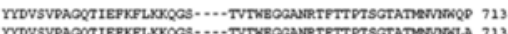

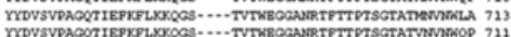

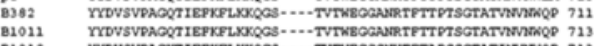

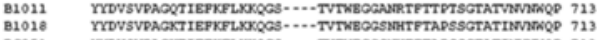

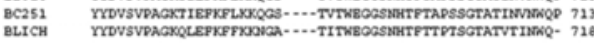

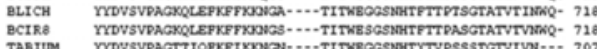

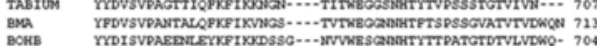

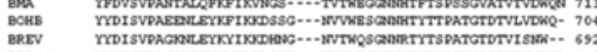

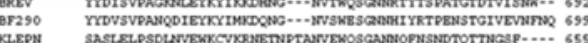

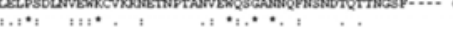

Fig. 2. Multiple alignment of the deduced amino acid sequences of T16 and pT16 with other alkaliphile CGTase producing bacteria and the resulted phylogenic tree. Amino acid sequences used in the analysis were from KLEPN, $K$. pneumoniae strain M5a1; BMACE, $B$. macerans strain NRRL B388; BLICH, B. licheniformis; B1011, Alkalophilic B. sp. strain 1011; BCIR8, B. circulans strain 8; B1018, Bacillus sp. strain B1018; B382, Alkalophilic B. sp. strain 38.; BC251, B. circulans strain 251; BOHB, B. ohbensis (strain C-1400); TABIUM, T. thermosulfurigenes EM1; BREV, Brevibacillus brevis strain CD162; BF290, B. firmus/lentus strain 290-3. Phylogenic tree was built by the neighbor joining method, implemented in the CLUSTALW program (Saiton and Nei, 1987). (A) alignment of amino acid sequences ofT16 and pT16 with 12 alkalophilic CGTase-producing bacteria (B) phylogenic tree analysis of A. 
(B)

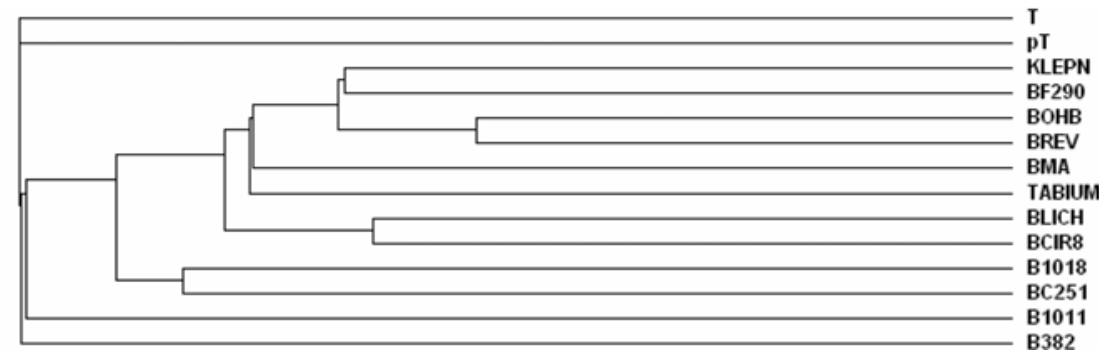

Fig. 2. Continued.

\section{Results and Discussion}

Nucleotide sequences and expression of CGTase genes. The CGTase gene from Paenibacillus sp. T16 was cloned using $E$. coli JM109 as a host. Transformant producing CGTase yielded clear halozone around the colony cultured on a starch-LB plate (containing 1.5\% agar, $100 \mu \mathrm{g} / \mathrm{ml}$ ampicillin and $1 \%$ potato soluble-starch on LB medium) stained with iodine solution. Plasmid DNA was prepared from the selected transformant. Nucleotide and amino acid sequence comparisons were performed using BLAST and Clustal W (Figs 1, 2) The deduced amino acid sequences of T16 and pT showed high homology to Alkalophilic Bacilli. The nucleotide sequences of $\mathrm{T}$ and pT show $96.6 \%$ similarlity. The homology score of deduced amino acid sequences between T16 and pT is 99\% with different amino acid residues are at position 340,438 , 712 and 713. Alignment of the amino acid sequences with

Table 1. Comparison of growth and some CGTase profiles between T16 and pT16

\begin{tabular}{lcc}
\hline & $\mathrm{T} 16$ & $\mathrm{pT} 16$ \\
\hline Growth & $37-50^{\circ} \mathrm{C}, \mathrm{pH} 10$ & $37^{\circ} \mathrm{C}, \mathrm{pH} 7$ \\
CGTase production & $37^{\circ} \mathrm{C}, \mathrm{pH} 10$ & $37^{\circ} \mathrm{C}, \mathrm{pH} 7$ \\
Time incubation & $72 \mathrm{~h}$ & $24 \mathrm{~h}$ \\
Optimum condition* & & \\
Dextrinizing & $60^{\circ} \mathrm{C}, \mathrm{pH} \mathrm{5-9}$ & $37-70^{\circ} \mathrm{C}, \mathrm{pH} \mathrm{5-9}$ \\
$\quad$ Cyclization & $60-70^{\circ} \mathrm{C}, \mathrm{pH} \mathrm{6.5}$ & $50-70^{\circ} \mathrm{C}, \mathrm{pH} \mathrm{6.5}$ \\
Stability* & & \\
Dextrinizing & $40-55^{\circ} \mathrm{C}, \mathrm{pH} \mathrm{7.0}$ & $40-65^{\circ} \mathrm{C}, \mathrm{pH} \mathrm{7.0}$ \\
Cyclization & $40-55^{\circ} \mathrm{C}, \mathrm{pH} \mathrm{7.0}$ & $40-60^{\circ} \mathrm{C}, \mathrm{pH} \mathrm{7.0}$ \\
\hline
\end{tabular}

*data obtained from purified enzymes and were from 3 duplicated experiments.
CGTases from other bacilli showed that T16 was $98 \%$ identical to Bacillus sp. \#1011 and Bacillus sp. Strain no.38-2, $87 \%$ to $B$. circulans strain 251. pT gave $98 \%$ identities to Bacillus sp. \#1011, 97\% to Bacillus sp. Strain no.38-2 and $87 \%$ to $B$. circulans strain 251 . The four conserved regions, in all members of the $\alpha$-amylase family (Nakajima et al., 1986: Kuruki and Imanaka, 1999), were also found in our parental and transformed CGTase.

To express the CGTase genes in T16 and pT16, optimum culture conditions were determined. T16 grew well in Horikoshi's medium pH 10 while pT16 had to be grown in LB medium $\mathrm{pH} 7$ to obtain optimum CGTase production. Addition of $1 \%$ soluble starch in LB medium did not affect the amount of CGTase produced but was included for enzyme detection on agar plate. Clear yellow zone around the colony against reddish-orange background indicated the presence of CGTase activity which subsequently produced CDs from the added soluble starch. Methyl orange was added to ruled out the effect of acid forming bacteria on phenolphthalein color change (Park et al., 1989). Optimum temperature for CGTase production was $37^{\circ} \mathrm{C}$ for both types of cells but pT16 required only $24 \mathrm{~h}$ culture time to produce maximum yield of CGTase, one-third that of T16 (Table 1).

Purifications and characterizations of CGTases. CGTases from the culture supernatant of both T16 and pT16 were purified in parallel by starch adsorption and phenyl sepharose column chromatography. T16 and pT16 showed a distinct difference from most CGTase that they did not bind to ion exchange columns, both DEAE cellulose and CM cellulose in phosphate buffer $\mathrm{pH}$ 7.0. They can be purified with $\beta-\mathrm{CD}$ affinity column or hydrophobic column such as phenyl sepharose. The crude enzyme yield from pT16 was about four

Table 2. Purification of CGTase from T16 and pT16

\begin{tabular}{|c|c|c|c|c|c|c|c|c|c|c|}
\hline \multirow[t]{2}{*}{ Fraction } & \multicolumn{2}{|c|}{$\begin{array}{c}\text { Total dextrinizing } \\
\text { activity } \\
\text { (units } \times 10^{-3} \text { ) }\end{array}$} & \multicolumn{2}{|c|}{$\begin{array}{l}\text { Total Protein } \\
\text { (mg) }\end{array}$} & \multicolumn{2}{|c|}{$\begin{array}{l}\text { Specific activity } \\
\text { (Units/mg) }\end{array}$} & \multicolumn{2}{|c|}{ Purification fold } & \multicolumn{2}{|c|}{$\begin{array}{c}\% \\
\text { Yield }\end{array}$} \\
\hline & $\mathrm{T} 16$ & pT16 & $\mathrm{T} 16$ & pT16 & T16 & pT16 & $\mathrm{T} 16$ & pT16 & T16 & pT16 \\
\hline Crude & 44.75 & 181.9 & 465.6 & 14.1 & 0.096 & 12.93 & 1 & 1 & 100 & 100 \\
\hline Starch adsorption & 27.32 & 35.0 & 8.8 & 1.1 & 3.11 & 31.82 & 32.3 & 3 & 61 & 19 \\
\hline Phenyl sepharose & 9.49 & 80.7 & 0.98 & 0.9 & 9.68 & 89.67 & 99 & 7 & 21.2 & 44 \\
\hline
\end{tabular}




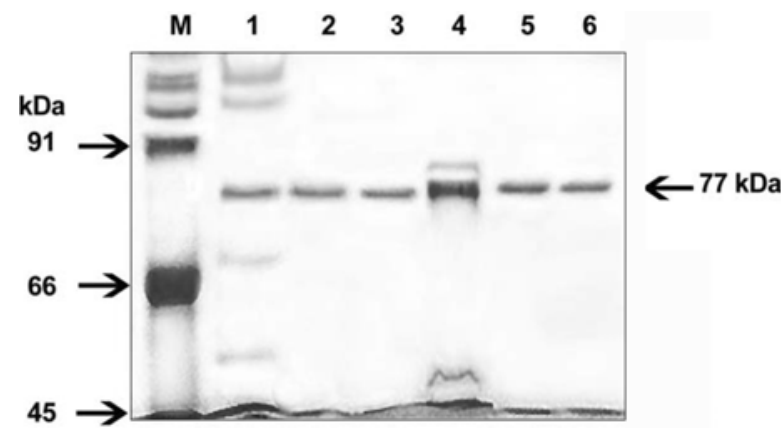

Fig. 3. SDS-PAGE analysis of CGTases from different purification steps. Protein samples from each purification steps of CGTases from T16 and pT16 were subjected to $7.5 \%$ SDS-PAGE. Lanes 1-3 were from wild type, lanes 4-6 from pT16. Lanes 1 and 4 were crude fractions. Lanes 2 and 5 were starch adsorbed fractions. Lanes 3 and 6 were phenyl sepharose fractions. M were molecular weight markers: $91 \mathrm{kDa}=$ phosphorylase $\mathrm{b}$, $66 \mathrm{kDa}=\mathrm{BSA}, 45 \mathrm{kDa}=$ ovalbumin.
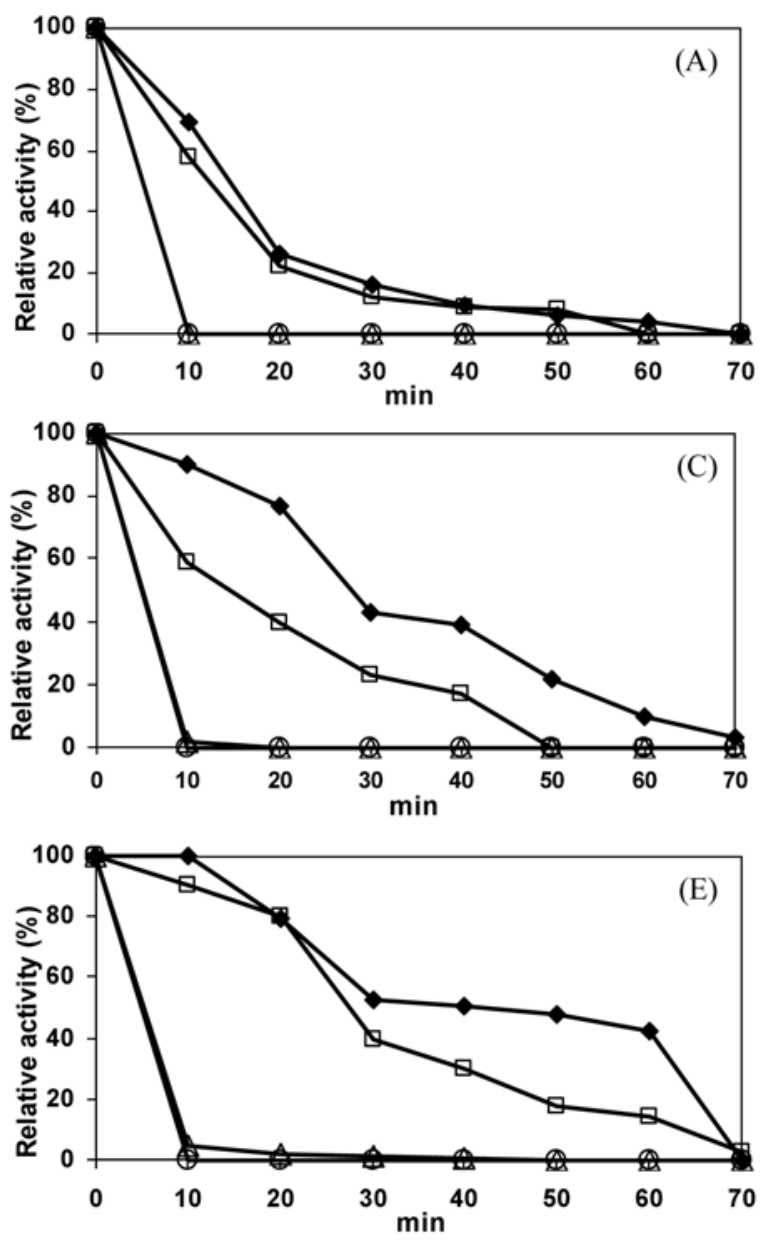

times higher than T16 (Table 2). After column chromatography, the protein yields from both types of cells were the same but enzyme yield was 9 times higher in pT16. Therefore, pT16 took shorter time and milder $\mathrm{pH}$ in production of CGTase with 9 times higher yield. The purified CGTases were subjected to gel electrophoresis as shown in Fig. 3 and the molecular weights deduced from SDS-PAGE were 77 kilodaltons for both enzymes. The optimum $\mathrm{pH}$ for dextrinizing and cyclization activities of purified CGTases from both sources were similar around pH 6.5 and 5-9 respctively. However, pT16 showed broader optimum temperatures for both dextrinizing and cyclization activities (Table 1). Both purified enzymes were tested for $\mathrm{pH}$ and temperature stabilities by incubating at various $\mathrm{pH}$ or temperautures up to $70 \mathrm{~min}$ before assaying their activity at their optimum temperature and $\mathrm{pH}$. The recombinant enzyme was more stable when incubated for one hour at high temperature up to $60^{\circ} \mathrm{C}$ when cyclization activity was retained up to $80 \%$ compared to $20 \%$ in T16. In the presence of $2 \%$ and $10 \%$ soluble starch, the temperature
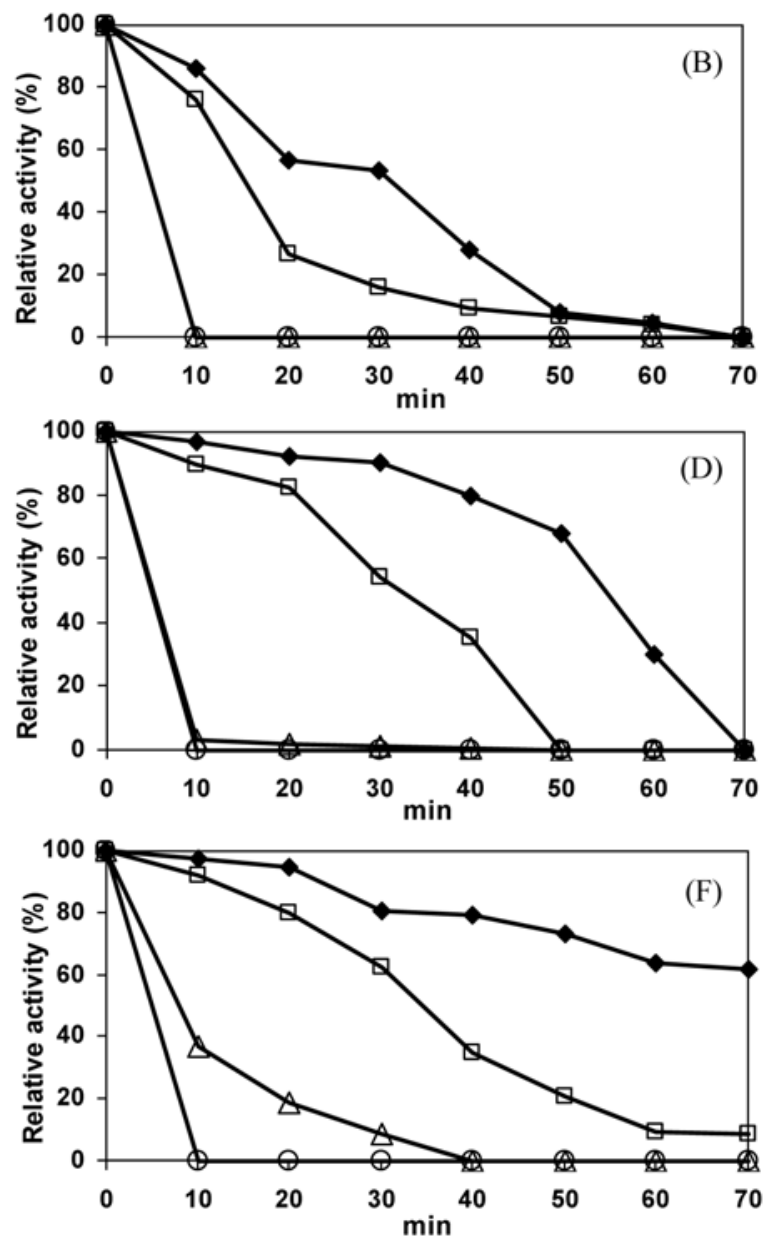

Fig. 4. Effect of various concentrations of starch on the thermostability of cyclization activity of CGTases from T16 and pT16. Purified CGTases from T16 (A, C, E) and pT16 (B, D, F) were pre-incubated at $60^{\circ} \mathrm{C}(\checkmark), 70^{\circ} \mathrm{C}(\square), 80^{\circ} \mathrm{C}(\triangle)$ and $90^{\circ} \mathrm{C}(\bigcirc)$ in the presence of different concentrations of soluble starch $0.2 \%$ (A, B); $2 \%(\mathrm{C}, \mathrm{D})$ and $10 \%(\mathrm{E}, \mathrm{F})$. Samples were taken at 10 minute intervals and assayed the cyclization activity at $60^{\circ} \mathrm{C}$ for $30 \mathrm{~min}$. The results were expressed as percent relative activity. 
Table 3. CD products of purified CGTases from T16 and pT16 determined by HPLC

\begin{tabular}{ccccc}
\hline & \multicolumn{3}{c}{ Area Peak } & Ratio \\
\cline { 2 - 4 } & $\alpha$-CD & $\beta$-CD & $\gamma$-CD & $\alpha: \beta: \gamma$ \\
\hline T16 & 3.294 & 3.45 & 5.41 & $0.95: 1: 1.57$ \\
pT16 & 2.96 & 11.66 & 5.95 & $0.25: 1: 0.51$ \\
\hline
\end{tabular}

*Data were average of 3 samples each.

stability of both enzymes were improved 4 times (Fig. 4 ). The result showed that purified CGTase from T16 and pT16 can work in the range of temperature $60-70^{\circ} \mathrm{C}$, at 80 and $90^{\circ} \mathrm{C}$ the cyclization activity was completely destroyed after preincubate for $10 \mathrm{~min}$. High concentration of starch maintained the cyclization activity at higher temperatures for longer time of incubation. CD products of the two enzymes analyzed by HPLC showed higher proportion of $\beta$-CD produced by the transformant (Table 3). T16 would be more beneficial for $\gamma$ $\mathrm{CD}$ production while pT16 more useful for $\beta-\mathrm{CD}$ production.

To determine the kinetic parameters of CGTase, parental CDs, $\alpha-, \beta$ - and $\gamma$-CDs; and derivatived CDs; glucosyl- $\alpha-C D$ (G- $\alpha-C D)$, glucosyl- $\beta-C D$ (G- $\beta-C D)$ and hydroxypropyl- $\beta-$ $\mathrm{CD}(\mathrm{HP}-\beta-\mathrm{CD})$ were used as substrates. In the primary screening, sugar acceptors such as maltose, sucrose, lactose, raffinose, trehalose were used to react with $\beta-\mathrm{CD}$ in the coupling reaction. Cellobiose was found to be the most active sugar acceptor while other sugars either react poorly or not at all. The kinetic parameters of the coupling activity of both enzymes were determined using various concentrations of $\alpha$-, $\beta$ - or $\gamma$-cyclodextrins and their derivatives $(0.5-15 \mathrm{mM})$ with $10 \mathrm{mM}$ cellobiose as glucosyl acceptor at $55^{\circ} \mathrm{C}$. When excess cellobiose was used with varied concentrations of natural
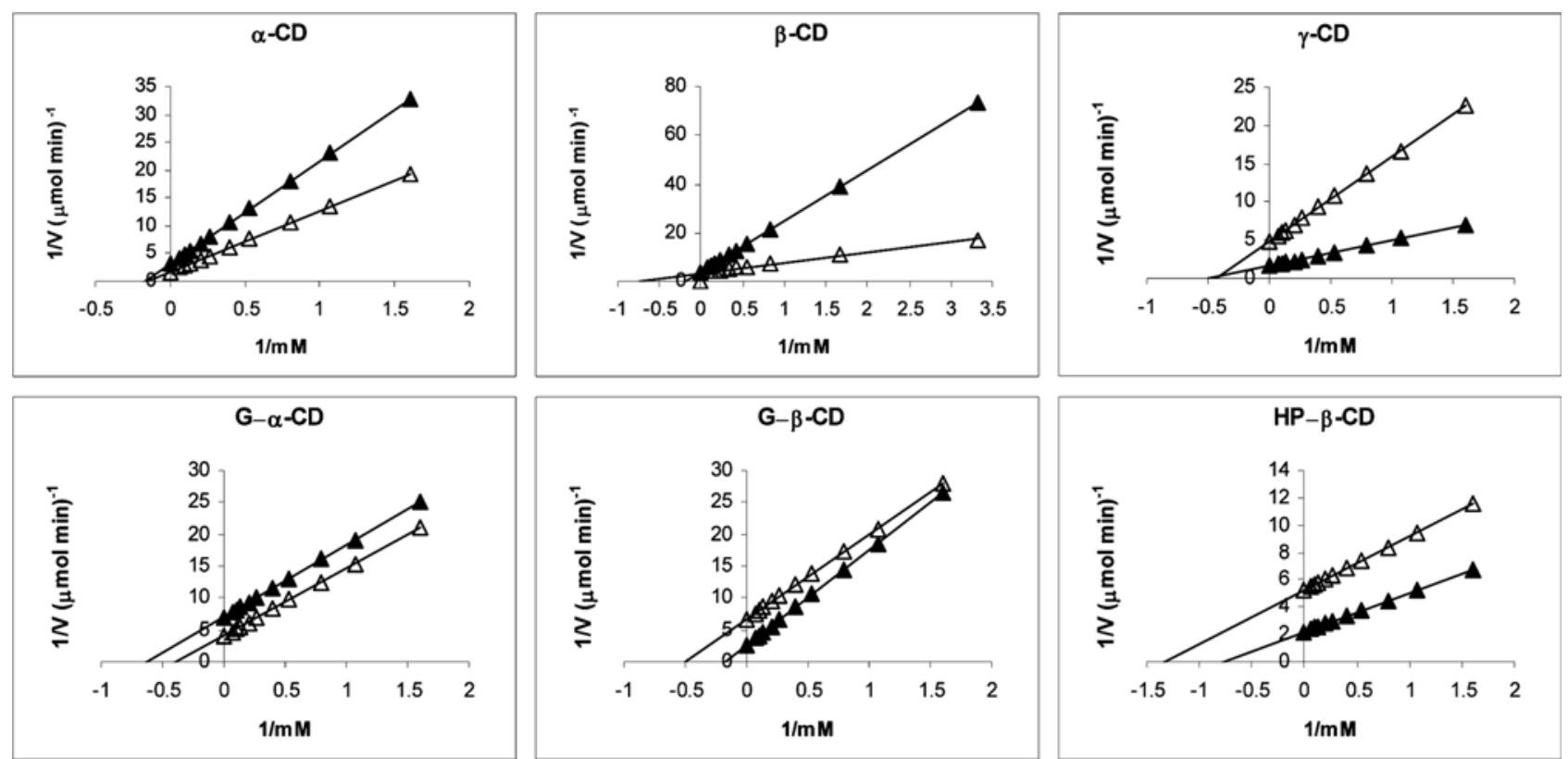

Fig. 5. Lineweaver-Burk plot of coupling reaction of CGTases from T16 $(\Delta)$ and pT16 $(\triangle)$ with cellobiose and various cyclodextrins as substrates. CGTase was incubated with $10 \mathrm{mM}$ cellobiose and various concentrations of each cyclodextrin in $50 \mathrm{mM}$ acetate buffer, $\mathrm{pH} 6.0$ at $40^{\circ} \mathrm{C}$ for 5 minutes. 0.2 unit of Aspergillus niger glucoamylase was added to convert linearized oligsaccharides to glucose. The amount of CD degraded was monitored by the dinitrosalicylic acid method.

Table 4. Kinetic parameters of CGTase from T16 and pT for different cyclodextrin substrates

\begin{tabular}{lccccccc}
\hline \multirow{2}{*}{ Substrate } & \multicolumn{2}{c}{$K_{\mathrm{m}}(\mathrm{mM})$} & \multicolumn{2}{c}{$k_{\text {cat }}\left(\mathrm{min}^{-1}\right)$} & \multicolumn{2}{c}{$k_{\text {cat }} / K_{\mathrm{m}}\left(\mathrm{mM}^{-1} \mathrm{~min}^{-1}\right)$} \\
\cline { 2 - 7 } & \multicolumn{2}{c}{$\mathrm{T} 16$} & $\mathrm{pT16}$ & $\mathrm{T} 16$ & $\mathrm{pT} 16$ & $\mathrm{~T} 16$ & $\mathrm{pT} 16$ \\
\hline$\alpha$-Cyclodextrin & $6.048 \pm 0.908$ & $6.299 \pm 1.956$ & 0.154 & 2.660 & 0.025 & 0.422 \\
$\beta$-Cyclodextrin & $5.266 \pm 0.975$ & $1.099 \pm 0.506$ & 0.120 & 1.182 & 0.023 & 1.075 \\
$\gamma$-Cyclodextrin & $2.082 \pm 0.298$ & $2.261 \pm 0.395$ & 5.566 & 0.945 & 2.674 & 0.418 \\
Glucosyl- $\alpha$-Cyclodextrin & $1.595 \pm 0.236$ & $2.615 \pm 0.982$ & 1.266 & 1.142 & 0.794 & 0.437 \\
Glucosyl- $\beta$-Cyclodextrin & $5.636 \pm 0.562$ & $1.963 \pm 0.680$ & 3.391 & 0.682 & 0.602 & 0.348 \\
Hydroxypropyl- $\beta$-Cyclodextrin & $1.291 \pm 0.318$ & $0.752 \pm 0.582$ & 0.215 & 0.879 & 0.166 & 1.170 \\
\hline
\end{tabular}

*Data were from 4 duplicated experiments. 
occurring CDs and some CDs derivatives, $K_{\mathrm{m}}$ for $\beta$-cyclodextrin and its derivatives were significantly lower in pT16 (Fig. 5, Table 4).

Since the nucleotide and deduced amino acid sequences of both T16 and pT16 were almost similar with difference at 4 positions, the differences observed in the $K_{\mathrm{m}}$ 's for cyclodextrins in coupling reaction, the optimum culture conditions and enzyme stability should be the results of the difference in cell type and intra and extra cellular environment. If the different characteristics observed were the effect of the change in 4 amino acid residues,it would imply their involvement at the active site of the recombinant enzyme. The cloning of T16 CGTase resulted in a transformant which gave better yield for CGTase at a shorter time with improved characteristics such as temperature and $\mathrm{pH}$ stability, and catalytic activity in coupling reaction. The transformant will be further studied for applications in industrial productions of $\mathrm{CDs}$ and oligosaccharides.

Acknowledgments This work was under the financial supports of Chulalongkorn University Ratchadapisek Research Fund to the Starch and Cyclodextrin Research Unit at the Department of Biochemistry, Faculty of Science Chulalongkorn University; Graduate School of Chulalongkorn University and the JSPSNRCT Core University Program.

\section{References}

Baudin, C., Pean, C., Perly, B. and Goselin, P. (2000) Inclusion of organic pollutants in cyclodextrin and derivatives. Int. J. Env. Anal. Chem. 77, 233-242.

Bollag, M. D. and Edelstein, J. S. (1991) Protein methods. In: Protein Methods, pp. 95-139, Wiley-Liss, Inc., New York, USA.

Bradford, M. M. (1976) A rapid and sensitive method for the quantitation of microgram quantities of protein utilizing the principle of protein-dye binding. Anal. Biochem. 72, 248-254.

Buschmann, H. J. and Schollmeyer, E. (2002) Applications of cyclodextrins in cosmetic products: a review. J. Cosmet. Sci. 53, $185-191$.

Fuwa, H. (1954) A new method for microdetermination of amylase activity by the use of amylose as substrate. $J$. Biochem. 41, 583-603.

Goel, A. and Nene, N. S. (1995) Modifications in the phenolphthalein method for spectrophotometric estimation of beta cyclodextrin. Starch/starke 47, 399-400.
Hirose, T. and Yamamoto, Y. (2001) Hinokitol containing cycloolefin polymer compositions and their molding with excellent antimicrobial and gas barrier properties. Japanese Patent JP 55480 .

Horikoshi, K. (1971) Production of alkaline enzymes by alkalophilic microorganisms. Agric. Biol. Chem. 35, 1783-1791.

Kato, K. and Horikoshi, K. (1984) Immobilized cyclodextrin glucanotransferase of an alkolophilic Bacillus sp. No38-2. Biotechnol. Bioeng. 26, 595-598.

Kuriki, T. and Imanaka, T. (1999) The concept of the $\alpha$-amylase family: structural similarity and common catalytic mechanism. J. Biosci. Bioeng. 87, 557-565.

Kobayashi, K., Kainuma, K. and Suzuki, S. (1978) Purification and some properties of Bacillus macerans cycloamylose (cyclodextrin) glucanotransferase. Carbohydr. Res. 61, 229-238.

Kobayashi, S. (1996) Cyclodextrin producing enzyme (CGTase); in Enzymes for Carbohydrate Engineering, Park, K.-H., Robyt, J. F., Choi, Y.-D. (eds.), pp. 23-41, Elsevier, Amsterdam, Netherlands.

Mabuchi, N. and Ngoa, M. (2001) Controlled release powdered flavour preparations and confectioneries containing preparations. Japanese Patent JP 128638.

Nakajima, R., Imanaka, T. and Aiba, S. (1986) Comparison of amino acid sequences of eleven different $\alpha$-amylases. Appl. Microbiol. Biotechnol. 23, 355-360.

Park, C. S., Park, K. H. and Kim, S. H. (1989) A rapid screening method for alkaline $\beta$-cyclodextrin glucanotransferase using phenolphthalein-methylorange-containing solid medium. Agric. Biol. Chem. 53, 1167-1169.

Rimphanitchayakit, V., Tonozuka, T. and Sakano, Y. (2005) Construction of chimeric cyclodextrin glucanotransferases from Bacillus circulans A11 and Paenibacillus macerans IAM1243 and analysis of their product specificity. Carbohydr. Res. 340, 2279-2289.

Saiton, N. and Nei, M. (1987) The neighbour joining method: a new method for reconstructing phylogenetic trees. Mol. Biol. Evol. 4, 406-425.

Sambrook, J., Fritsch, E. and Maniatis, T. (1989) Molecular cloning: A Laboratory Manual. In: Molecular cloning: $A$ Laboratory Manual. New York, USA: Cold Spring Harbor Laboratory Press, New York, USA.

Schmid, G. (1989) Cyclodextrin glucanotransferse production: yield enhancement by overexpression of cloned genes. Trends in Biotechnol. 7, 244-248.

Stella, V. J. and Rajewski, R. A. (1997) Cyclodextrins: their future in drug formulation and delivery. Pharm. Res. 14, 556-567.

Szejtli, J. (1998) Introduction and general overview of cyclodextrin chemistry. Chem. Rev. 98, 1743-1753. 